\section{Flere bør behandles for voksenvannhode}

\author{
For få pasienter tilbys operasjon for sykdommen normaltrykkshydro- \\ cephalus, også kalt voksenvannhode. Nå kan en ny undersøkelses- \\ metode føre til at flere får behandling.
}

Voksenvannhode er en av de få årsakene til demens som effektivt kan behandles. Sykdommen gir langsomt innsettende ustøhet, demens og urinlekkasje, og behandlingen er shuntoperasjon - der cerebrospinalvæsken dreneres fra hjernen til bukhulen.

- Ingen har visst sikkert hvor vanlig sykdommen er, og ingen har vært enige om hvordan disse pasientene skal utredes, sier overlege og spesialist i nevrologi Are Brean.

I sin avhandling har han funnet en sannsynlig forekomst på 5,5 per 100000 innbyggere per år, mens bare 1 per 100000 innbyggere blir behandlet for sykdommen per år i Norge.

- Det er dermed grunn til å tro at vi opererer for få, sier Brean.

Han har sett på mulige strategier for utredning av sykdommen. Det viser seg at en ny metode for analyse av hjernens trykk målt lumbalt ofte kan erstatte målinger foretatt direkte i hjernen hos disse pasientene.

- Den nye metoden for lumbal trykkmåling predikerer shuntrespons bedre enn de tradisjonelle metodene og kan derfor brukes til å forutsi hvem som vil bli bedre av behandling, sier Brean.

Metoden er ikke like god som målinger direkte $\mathrm{i}$ hjernen, men den gjør at langt flere pasienter kan utredes ved sine lokale nevrologiske avdelinger istedenfor å måtte innlegges i nevrokirurgiske spesialavdelinger.

- Dette gir en lavere terskel for utredning av de demenspasientene der man mistenker normaltrykkshydrocephalus. På den måten kan det være med på å sikre at de rette pasientene blir behandlet, sier Brean.

\section{Eline Feiring}

eline.feiring@legeforeningen.no Tidsskriftet

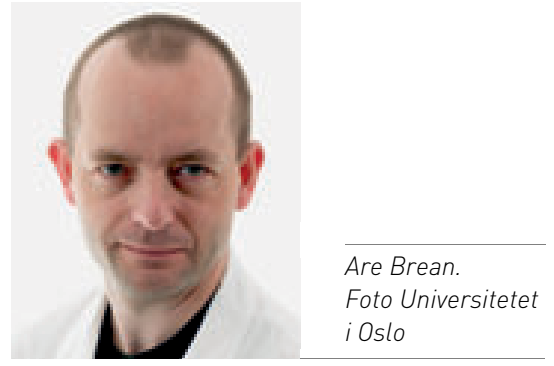

Disputas

Are Brean disputerte for ph.d.-graden 29.4. 2011 ved Universitetet i Oslo med avhandlingen Idiopathic normal pressure hydrocephalus in neurological practice - A study of epidemiology and methods for selection of patients for surgery.

Ordforklaringer

Shuntoperasjon: Innsetting av drensrør til hjernens ventrikkelsystem. Drensrøret (shunten)

legges under huden og drenerer overskuddsvæske, vanligvis til fri bukhule.

\title{
Lite liv - hva skal man gjøre?
}

\section{Bekymring for lite liv er en vanlig årsak til konsultasjoner i tredje trimester og er ofte en utfordring i svangerskapsomsorgen.}

Det finnes ingen enhetlig definisjon på lite liv. Barn i magen sparker og oppfører seg ulikt, slik at det er hver enkelt kvinnes subjektive oppfatning som er avgjørende.

- Det er viktig at gravide blir kjent med barnet i magen slik at de kan reagere når aktiviteten endrer seg, sier lege Julie Victoria Holm Tveit.

I sin avhandling Decreased fetal movements in late pregnancy-importance today? har Holm Tveit og medarbeidere vist at det er muligheter for kvalitetsforbedring gjennom økt årvåkenhet og adekvat håndtering av kvinner med lite liv. Formålet med studien, som inkluderte 14 sykehus på Østlandet og Bergen, var å vite mer om hvilke kvinner som hadde høyest risiko, deres atferd ved bekymring og helsevesenets håndtering, utredning $\mathrm{og}$ behandling. De ville også finne ut hvilken informasjon som ble gitt og hvordan det gikk med svangerskapet og barnet.

- Vi fant at kvinner med lite liv hadde en økt risiko for bl.a. for tidlig fødsel samt veksthemning og død hos barnet. Mors karakteristika og atferd i forhold til hvor lenge hun ventet med sin bekymring var av betydning. Informasjonen gitt til gravide om «normal» aktivitet hos barnet og håndtering $\mathrm{av}$ kvinnene ved de ulike sykehusene varierte. Som et resultat av funnene ønsket vi å studere effekten av å gi informasjon til gravide om barnets aktivitet samtidig som man implementerte retningslinjer for utredning av kvinner med lite liv. Vi fant at førstegangsfødende kom både raskere og tidligere med sin bekymring. Bruk av ultralyd økte, mens antall innleggelser og kvinner satt opp til ny kontroll ble redusert. Andel fortidligfødsler, veksthemning og overføring til nyfødtintensivavdeling forble uendret, sier Tveit.

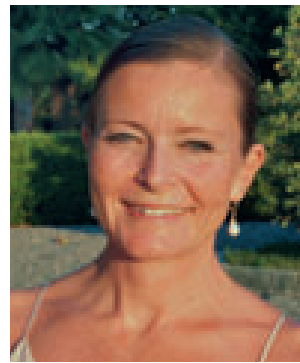

Julie Victoria Holm Tveit. Foto Landsforeningen uventet barnedød

Disputas

Julie Victoria Holm Tveit disputerte for ph.d.graden ved Universitetet i Oslo 6.5. 2011 med avhandlingen Decreased fetal movements in late pregnancy - importance today? 